DOI https://doi.org/10.30525/978-9934-588-91-4-17

\title{
НУМІЗМАТИЧНІ АРТЕФАКТИ ЯК ДОКАЗИ ІСНУВАННЯ ВАСАЛЬНОЇ ЗАЛЕЖНОСТІ ДМИТРА ДОНСЬКОГО ВІД ЗОЛОТОї ОРДИ
}

\author{
Ніколаюк Т. А. \\ кандидат історичних наук, дочент, \\ завідувач кафедрою культури і сочіально-гуманітарних дисциплін \\ Національної академї образотворчого мистецтвва та архітектури \\ м. Київ, Україна
}

Офіційні російські історики створили багато міфологем про взаємовідносини московських князів із ординськими правителями. Аби заперечити активну співпрацю Рюриковичів із Золотою Ордою, за вказівкою московських володарів у середні віки були винищені ханські ярлики, які підтверджували їхню васальну залежність від золотоординських урядів $[1$, c. 188]. Пізніше царські історики, які прославляли Дмитра Донського за його перемогу над татарами на Куликовому полі у 1380 році, вимушені були наводити різні причини для пояснення факту поновлення васальних стосунків між героєм «кровавого побоища, ставшего знаком торжества Европы над Азией», і татарським ханом Тохтамишем [2].

Дійсно, героїчний образ Дмитра Донського як борця 3 татарами спростовується його співпрацею 3 ними. Зображення на монетах, відчеканених у Москві впродовж 1381-1389 рр., тобто під час правління Дмитра Донського, підтверджують існування міцних економічних зв'язків між московським князем та ординською адміністрацією.

Як відомо, утвердження на престолі у Золотій Орді з 1381 року легітимного хана Тохтамиша замість узурпатора темника Мамая було вигідне правителям Заліського улусу Золотої Орди. Віднині князіРюриковичі достоменно знали, з ким саме потрібно вести перемовини, до кого посилати посольство, привозити дарунки, а також хто видаватиме ярлик на княжіння в їхніх удільних князівствах. Тому вони швидко відновили дипломатичні стосунки із Тохтамишем, який надіслав до підлеглих князів-васалів своїх дипломатів. Як свідчить «Рогожский летописец», Рюриковичі, в тому числі й московський князь Дмитро Донський, «пословъ его отпустиша съ честію и съ дары, а сами на зиму ту и на ту весну за ними отъпустиша конждо своихъ киличеевъ со многими дары ко цирю Тохтамышю» [3, с. 142]. Пізніше хан примусив заліських князів, у тому числі й Дмитра Івановича, виплачувати щорічні податки, чим остаточно затвердив їхню васальну залежність від Орди. 
Для економічних розрахунків найзручніше використовувати монети. Тому для забезпечення виплати татарської данини у Москві з 1381 року розпочали карбувати монети на основі московського срібного рубля злитка. Як стверджував фахівець із радянської нумізматики Спаський I.Г., «монетная чеканка начиналась в мастерских ремесленников - серебряников, работавших не столько по заказу, сколько по разрешению князей... Великий князь имел собственного серебряника-денежника, или даже нескольких ремесленников, откупавших у князя право чеканить монету, m. е. принимать заказы на ее изготовление...» [4].

Уважний розгляд зображень на аверсі та реверсі монет, випущених за часів правління Дмитра Донського, викликає велике здивування: на зворотному боці московських монет можна побачити арабський напис 3 ім'ям хана Золотої Орди Тохтамиша, а саме: «Султан Абдуллах або Султан Тохтамиш хан, нехай живе довго». Російські історики давно намагались пояснити цей дивний факт. Наприклад, Спаський І.Г. стверджував, що «в действительности же здесь сказалось прежде всего активное восстановление в новых условиях прочных связей Руси с рынками Ближнего Востока через Поволюье...» [4].

Коментувати назва Русь, яке вживається радянським істориком нумізматом по відношенню до Заліського улусу Золотої Орди, ми зараз не будемо (авторка раніше це зробила в інших своїх роботах [5]), а ось версія Спаського I.Г. про причини використання на московських монетах арабського письма з ім'ям Тохтамиша не витримує ніякої критики.

Нам здається, що переконливішим можна вважати пояснення відомого царського спеціаліста із нумізматики Орєшнікова О. В., якій брав участь у систематизації та описі монет із зібрання Імператорського історичного музею (сьогодні - Державний історичний музей, скорочено ДІМ). Він ствержував, що карбування на монетах імені діючих на той час татарських правителів - «царів» - була одним із звичайних виразів васальної залежності заліських князів від золотоординських ханів: «Князья великие и удельные помещзали кроме своего имени, еще имя иарствуюшего кипчакского хана и таким образом выражали, согласно господствующему на всем мусульманском Востоке обычаю, признание его верховенства над собою и своей покорности ему. Сюда относятся деньги Димитрия Донского... с прекрасно вырезанною арабскою надписью: султан Токтамыш хан, да продлится его жизнь. Обе монеты относятся ... к 1383-1389 году» [6, с. 82].

Отже, окремі царські історики вже давно визнали, що написи на московських монетах із вихвалянням хана Тохтамиша яскраво свідчать про підлегле становище Дмитра Донського від татарського уряду.

Також викликають інтерес зображення на лицевій стороні монет Дмитра Донського, які поділяються на декілька типів. На монетах першого типу, наприклад, зображена людина по пояс 3 сокирою i 
шаблею. Але найбільшу цікавість викликає малюнок на монетах четвертого типу - на них розміщено фігуру півня 3 маленькою зірочкою під ним і кількома кульками під дзьобом.

\section{Гроші Московського улусного васала Дмитра Донського арабсь- кою мовою із вихваляннями господаря - хана Орди.}

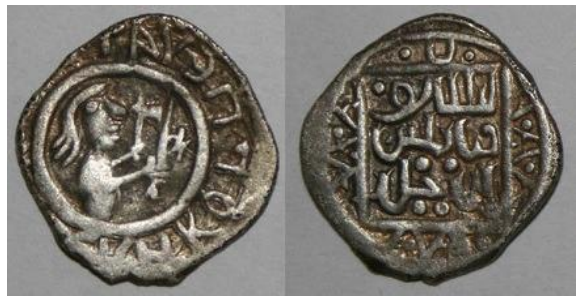

Рис. 1. Один 3 типів монет Дмитра Донського 3 профільним поясним зображенням воїна з сокирою і шаблею в руках на аверсі монети та надпису арабською мовою на реверсі;

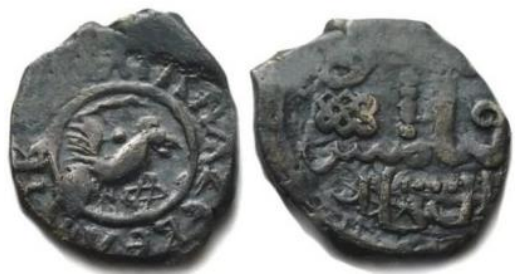

Рис. 2. Тип монет часів Дмитра Донського із зображенням ісламського символу (півня) на аверсі монети та надпису арабською мовою на реверсі.

Зображення півня на монетах Дмитра Донського пояснюється тим, що наприкінці XIV століття у Золотій Орді державною релігією став іслам. Для мусульман півень є символом торжества Аллаха, його крик пробуджує мусульманина на ранкову молитву [7]. Тобто можна стверджувати, що хан Тохтамиш змусив свого васала Дмитра Донського викарбовувати на лицевій стороні московських монет образ шанованого в мусульманських країнах півня, а на зворотному боці мовою Корану вихвальну оду, щоб посилити свій статус господаря над Московським улусом.

Отже, аналіз нумізматичного матеріалу часів правління Дмитра Донського доводить, що московський князь залишався васалом Орди до кінця свого життя. Ось як описує цього персонажа історик Костомаров M.I.: «Сам Дмитрий не был князем, способньм мудростью правления облегчить тяжелую судьбу народа... последствием всей его деятель- 
ности было то, что разоренная Русь опять должна была ползать $и$ унижаться перед издыхающей Ордой» [8].

\section{Література:}

1. Почекаев Р.Ю. Право Золотой Орды. / Редактор И.М. Миргалев. Казань, 2009. 260 с.

2. Соловьев С.М. История России с древнейших времен. Сочинения: в 18 кн. Т. 3. Глава 7. Москва, 1993-1998.

3. URL: http://militera.lib.ru/common/solovyev1/index.html (дата звернення: 17.10.2020)

4. ПСРЛ (Полное собрание русских летописей), том XV. Издание 2-е. Вып. 1. Рогожский летописец. Пг., 1922. Москва, 2000. 216 с.

5. URL: http://psrl.csu.ru/toms/Tom_15.shtml (дата звернення: 17.10.2020)

6. Спасский И.Г. Русская монетная система. Москва, 1957. 121 с. URL: http://vsemonetki.ru/books/item/f00/s00/z0000008/st006.shtml (дата звернення: 17.10.2020)

7. Ніколаюк Т. А. Світоглядні міфологеми у тлумаченні історичного минулого України та Росії. Практична філософія. 2018. № 4. С. 88-100; Ніколаюк Т. А. Світоглядні міфологеми у тлумаченні історичного минулого України та Росії. Частина 2. Практична філософія. 2019. № 1. С. 88-103.

8. Орешников А.В. Русские монеты до 1547 года. Императорский Российский исторический музей им. Императора Александра III. Описание памятников. Вып. I. Москва, 1896. 226 с. URL: https://www.russian-money.ru/Information/Oreshnikov/P81.GIF (дата звернення: 17.10.2020).

9. Бурова И. И. Хадисы о пророке Мухаммеде. Москва, 2013. 304 с. (цветные иллюстрации) Хадіс 8.21

10. URL: https://religion.wikireading.ru/223691 (дата звернення: 17.10.2020)

11. Костомаров Н.И. Русская история в жизнеописаниях ее главнейших деятелей. Глава II. Москва, 2015. 1024 с.

12. URL: http://www.spsl.nsc.ru/history/kostom/kostlec.htm (дата звернення: 17.10.2020). 